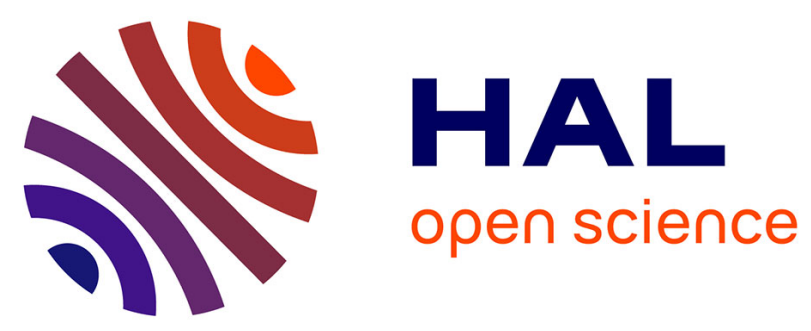

\title{
Regulation of hepatic cardiolipin metabolism by TNF $\alpha$ : Implication in cancer cachexia
}

Laure Peyta, Kathleen Jarnouen, Michelle Pinault, Cédric Coulouarn, Cyrille Guimaraes, Caroline Goupille, Jean-Paul Pais de Barros, Stephan Chevalier, Jean-François Dumas, François Maillot, et al.

\section{To cite this version:}

Laure Peyta, Kathleen Jarnouen, Michelle Pinault, Cédric Coulouarn, Cyrille Guimaraes, et al.. Regulation of hepatic cardiolipin metabolism by $\mathrm{TNF} \alpha$ : Implication in cancer cachexia. BBA - Biochimica et Biophysica Acta, 2015, 1851 (11), pp.1490-1500. 10.1016/j.bbalip.2015.08.008 . hal-01197346

\section{HAL Id: hal-01197346 \\ https://hal-univ-rennes1.archives-ouvertes.fr/hal-01197346}

Submitted on 21 Sep 2015

HAL is a multi-disciplinary open access archive for the deposit and dissemination of scientific research documents, whether they are published or not. The documents may come from teaching and research institutions in France or abroad, or from public or private research centers.
L'archive ouverte pluridisciplinaire HAL, est destinée au dépôt et à la diffusion de documents scientifiques de niveau recherche, publiés ou non, émanant des établissements d'enseignement et de recherche français ou étrangers, des laboratoires publics ou privés. 


\section{Regulation of hepatic cardiolipin metabolism by TNF $\alpha$ : implication in cancer cachexia}

Laure Peyta $^{1}$, Kathleen Jarnouen ${ }^{2,3}$, Michelle Pinault ${ }^{1}$, Cedric Coulouarn ${ }^{2,3}$, Cyrille Guimaraes ${ }^{1}$, Caroline Goupille ${ }^{1,5}$, Jean-Paul Pais de Barros ${ }^{4}$, Stephan Chevalier ${ }^{1}$, Jean-François Dumas ${ }^{1}$, François Maillot ${ }^{1,5}$, Grant M. Hatch ${ }^{6}$, Pascal Loyer ${ }^{2,3}$ and Stephane Servais ${ }^{1}$.

${ }^{1}$ Inserm UMR1069, Nutrition, Croissance et Cancer, Université François Rabelais de Tours- 10, bd Tonnellé - 37032 Tours Cedex, France.laure.peyta@etu.univ-tours.fr; michelle.pinault@univ-tours.fr; cyrille.guimaraes@gmail.com; caroline.goupille@univ-tours.fr, stephan.chevalier@univ-tours.fr; jeanfrancois.dumas@univ-tours.fr; maillot@med.univ-tours.fr; stephane.servais@univ-tours.fr

${ }^{2}$ Inserm UMR S-991, Foie, Métabolismes et Cancer, CHU Pontchaillou, 2 rue Henri Le Guilloux, 35033 Rennes, France.kathleen.jarnouen@univ-rennes1.fr; cedric.coulouarn@univ-rennes1.fr; pascal.loyer@univrennes1.fr

${ }^{3}$ Université de Rennes 1, 2 rue du Thabor CS46510, 35065 Rennes cedex, France.

${ }^{4}$ Plateforme de Lipidomique. INSERM UMR866 / LabEx LipSTIC, 15 Bd Mal de Lattre de Tassigny, 21000 Dijon,France.jppais@u-bourgogne.fr

${ }^{5}$ CHRU de Tours, Département de Médecine Interne, 2, boulevard Tonnellé - 37044 Tours cedex 9, France.

${ }^{6}$ Department of Pharmacology and Therapeutics, Biochemistry and Medical Genetics, Faculty of Health Sciences, Center for Research and Treatment of Atherosclerosis, DREAM Children's Hospital Research Institute of Manitoba, University of Manitoba, 513 - 715 McDermot Avenue Winnipeg MB R3E 3P4, Manitoba, Canada.ghatch@chrim.ca

*Corresponding author:

Stephane SERVAIS, Laboratoire Nutrition, Croissance et Cancer - Inserm UMR1069

Faculté de Médecine - 10, bd Tonnellé - 37032 Tours Cedex

Email stephane.servais@univ-tours.fr; Phone +33 2.47.36.60.59; Fax +33247366226

Running title: cardiolipin metabolism in cancer cachexia 
Abbreviations: ALCAT1: acyl-CoA:lysocardiolipin acyltransferase; CDP-DAG: diphosphate-1,2-diacyl-sn-glycerol; CDS:cytidine-5'-diphosphate-1,2-diacyl-sn-glycerol synthase; CL: cardiolipin; CLS: cardiolipin synthase; DMSO: dimethylsulfoxide; ETS: electron transfert system; FCCP: Carbonyl cyanide-4-(trifluoromethoxy)phenylhydrazone; GAPDH: glyceraldehyde 3-phosphate dehydrogenase; Hsc70: Heat shock cognate 70 kDa; iPLA2 $\gamma$ :calcium independent phospholipase A2 gamma; MLCL AT-1: monolysocardiolipin acyltransferase-1; MLCL: monolysocardiolipin; PC: phosphatidylcholine; PCC: peritoneal carcinosis induced cachexia; PE: phosphatidylethanolamine; PF: pair fed; PG: phosphatidylglycerol; PGC-1 $\alpha$ : peroxisome proliferator-activated receptor gamma coactivator 1-alpha; PGP: phosphatidylglycerol phosphate; PGPP: phosphatidylglycerol phosphate phosphatase; PGPS: phosphatidylglycerol phosphate synthase; PI: phosphatidylinositol; PS: phosphatidylserine; SM: sphyngomyelin; TAZ: tafazzin; TNF $\alpha$ : tumor necrosis factor alpha; VDAC: voltage-dependent anion channel. 


\section{Abstract}

Cardiolipin (CL) content accumulation leads to an increase in energy wasting in liver mitochondria in a rat model of cancer cachexia in which tumor necrosis factor alpha (TNF $\alpha)$ is highly expressed. In this study we investigated the mechanisms involved in liver mitochondria CL accumulation in cancer cachexia and examined if $\mathrm{TNF} \alpha$ was involved in this process leading to mitochondrial bioenergetics alterations. We studied gene, protein expression and activity of the main enzymes involved in CL metabolism in liver mitochondria from a rat model of cancer cachexia and in HepaRG hepatocyte-like cells exposed to 20 $\mathrm{ng} / \mathrm{ml}$ of TNF $\alpha$ for $12 \mathrm{~h}$. Phosphatidylglycerolphosphate synthase (PGPS) gene expression was increased 2.3-fold $(\mathrm{p}<0.02)$ and cardiolipin synthase (CLS) activity decreased $44 \%(\mathrm{p}<0.03)$ in cachectic rat livers compared to controls. CL remodeling enzymes monolysocardiolipin acyltransferase (MLCL AT-1) activity and tafazzin (TAZ) gene expression were increased 30\% (p<0.01) and 50\% ( $\mathrm{p}<0.02)$, respectively, in cachectic rat livers compared to controls. Incubation of hepatocytes with TNF $\alpha$ increased CL content $15 \%(p<0.05)$, mitochondrial oxygen consumption 33\% $(p<0.05)$, PGPS gene expression $44 \%(p<0.05)$ and MLCL AT-1 activity $20 \%(\mathrm{p}<0.05)$ compared to controls. These above findings strongly suggest that in cancer cachexia, TNF $\alpha$ induces a higher energy wasting in liver mitochondria by increasing CL content via upregulation of PGPS expression.

Highlights:

- First demonstration of liver cardiolipin metabolism alteration in cancer induced cachexia

- Direct implication of TNF $\alpha$ in mitochondrial energy wasting via cardiolipin modulation

- Increasing knowledge on cellular mechanism of liver energetic alteration during cancer cachexia

Key words: cardiolipin biosynthesis, cytokines, mitochondria, energy wasting, liver, cardiolipin remodeling, inflammation. 


\section{INTRODUCTION}

Cancer cachexia is a multifactorial syndrome characterized by a progressive deterioration of nutritional status due to whole body negative energy balance driven by a reduced calorie intake (anorexia) and/or inappropriate energy expenditure (hypermetabolism) and systemic inflammation [1]. Depending on tumor type, cancer cachexia occurs in 30 to $80 \%$ of patients [2-4]. The negative energy balance induces white adipose tissue and skeletal muscle wasting which both impair quality of life and increase chemoand radiotherapy associated toxicity in patients [5]. The mechanisms of cancer cachexia have not been fully elucidated and this explains the difficulties in managing therapy and restoring nutritional status in cancer patients. We recently investigated mechanisms involved in the hypermetabolism observed during cachexia in a rat preclinical model peritoneal carcinosis [6]. We demonstrated that peritoneal carcinosisinduced cachexia was associated with bioenergetic alterations in the healthy liver. Liver mitochondria from cachectic rats displayed significant increases in energy wasting and this was associated with reduced ATP production yield. Interestingly, liver mitochondria cardiolipin (CL) content was increased in cachectic rats in comparison to healthy controls [7]. Importantly, CL content was positively correlated with this increase in energy wasting. We subsequently demonstrated in vitro that CL content was indeed directly involved in the increase in liver mitochondria energy wasting [8]. Cancer cachexia not only affected the CL content but also CL fatty acid composition in liver mitochondria [6]. The mechanisms driving such liver mitochondrial CL alterations in cancer cachexia have not been investigated.

CL [bis-(1,2-diacyl-sn-glycero-3-phospho)-1'-3'-sn-glycerol] is a major and specific phospholipid of the mitochondria and on the inner membrane CL is required for the activity of a number of key mitochondrial enzymes involved in cellular energy metabolism $[9,10]$. CL metabolism is complex and includes both de novo biosynthesis and remodeling. In mammals, the first step of CL de novo synthesis is catalyzed by cytidine-5'-diphosphate-1,2-diacyl-sn-glycerol synthase (CDS) producing diphosphate-1,2diacyl-sn-glycerol (CDP-DAG). Phosphatidylglycerol phosphate synthase (PGPS), the committed step of CL synthesis, catalyzes the formation of phosphatidylglycerol phosphate (PGP) from CDP-DAG. PGP is then dephosphorylated to phosphatidylglycerol (PG) by PGP phosphatase (PGPP) [11]. The final step is catalyzed by CL synthase (CLS) [12]. At this step CL is considered as nascent and will undergo 
maturation by fatty acyl remodeling. Remodeling allows the formation of mature CL with defined fatty acyl composition. Initially deacylation by calcium independent phospholipase $\mathrm{A}_{2}\left(\mathrm{PLA}_{2} \gamma\right)$ as well as other putative phospholipases [13] produces monolysocardiolipin (MLCL), this step is followed by resynthesis catalyzed by at least 3 enzymes: monolysocardiolipin acyltransferase-1 (MLCL AT-1), acylCoA:lysocardiolipin acyltransferase (ALCAT1) or the transacylase tafazzin (TAZ) [14-16].

Whereas there is a relative consensus about CL de novo synthesis in yeast and lower eukaryotes, regulation of the CL metabolic enzymes in higher eukaryotes is still poorly understood [17]. Previous studies in heart and myoblasts indicated that CL metabolism was upregulated by peroxisome proliferatoractivated receptor $\alpha$ agonist [18] and peroxisome proliferator-activated receptor gamma coactivator 1alpha (PGC-1 $\alpha$ ) [19]. Since inflammation is a hallmark of cancer cachexia [20], we hypothesized that inflammatory cytokines may play a significant role in the dysregulation of CL metabolism in cancer cachexia and energy wasting increase in liver mitochondria. Our previous study clearly highlighted TNF $\alpha$ as the major cytokine (14-fold elevated serum concentration) in our preclinical model of cancer cachexia [6].

The aim of the present study was to investigate the mechanisms responsible for liver mitochondrial CL accumulation and its altered fatty acid composition in cancer cachexia. We examined gene expression, protein expression and activity of the main enzymes involved in CL biosynthesis and remodeling in liver mitochondria from a preclinical model of cancer cachexia [6]. In addition, we investigated the in vitro effect of the proinflammatory cytokine TNF $\alpha$ on CL metabolism related enzymes in the human hepatoma HepaRG hepatocyte-like cells that retain many characteristics of primary human hepatocytes [21]. 


\section{MATERIALS AND METHODS}

\section{Materials}

Undifferentiated HepaRG cells (BioPredict International France, Batch number HPR101007-A), $\left[{ }^{14} \mathrm{C}\right]$ Glycerol-3-phosphate, $\left[5-{ }^{3} \mathrm{H}\right]$ Cytidine 5 '-riphosphate, $\left[1-{ }^{14} \mathrm{C}\right]$ palmitoyl-phosphatidylcholine, [1${ }^{14}$ C]linoleoyl-Coenzyme A were obtained from Dupont, Mississauga, Ontario, Canada or Amersham, Oakville, Ontario, Canada. $\left[{ }^{14} \mathrm{C}\right] \mathrm{PG}$ was synthesized from $\left[{ }^{14} \mathrm{C}\right]$ glycerol-3-phosphate as described [22].

\section{Animal model}

Liver from cachectic (peritoneal carcinosis induced cachexia, PCC) and healthy (pair fed, PF) rats were obtained as previously described [6].

\section{Cell culture and treatments for in vitro inflammation study}

As previously described [21] HepaRG cells line were cultivated in William's E medium supplemented with $10 \%$ fetal bovine serum, $100 \mathrm{U} / \mathrm{ml}$ penicillin, $100 \mu \mathrm{g} / \mathrm{ml}$ streptomycin, $5 \mu \mathrm{g} / \mathrm{ml}$ insulin, and $50 \mu \mathrm{M}$ hydrocortisone hemisuccinate. After 2 weeks, the medium was supplemented with $2 \%$ dimethyl sulfoxide (DMSO) and the cells were cultured for 2 more weeks. HepaRG hepatocytic cells from DMSO treated cultures were selectively detached using gentle trypsination and seeded at high density for cytokine treatments. Cells were incubated for $12 \mathrm{~h}$ with $20 \mathrm{ng} / \mathrm{ml}$ of TNF $\alpha$.

\section{Generation of SiPGPS HepaRG Cells}

The validated siRNA (sc-94116, Santa Cruz Biotechnology) was used for knocking down the expression of PGPS in HepaRG hepatocyte-like cells. The siRNA (s1227, Ambion $\left.{ }^{\circledR}\right)$ targeting albumin was used as control. Electroporation was performed using the Neon ${ }^{\circledR}$ transfection system (Life Technologies) available at the SynNanoVect core facility (Biogenouest, Rennes, France) as previously described [23]. Briefly, differentiated HepaRG hepatocyte-like cells were detached by trypsin incubation, then, $10^{6}$ cells were electroporated with 40 picomoles of siRNA and the following parameters: one pulse of 1500 volts during $20 \mathrm{~ms}$. Cells were immediately seeded at the density of $2.5 \times 10^{5}$ cells/cm2 and cultured in William's 
E medium supplemented with $2 \%$ DMSO. Twenty four hours after electroporation, medium was discarded and cells were cultured in William's E medium without fetal calf serum and DMSO for $24 \mathrm{~h}$ prior stimulation with $20 \mathrm{ng} / \mathrm{mL}$ of $\mathrm{TNF} \alpha$ for $12 \mathrm{~h}$.

\section{Transmission electron microscopy for mitochondrial content determination}

HepaRG cells and liver biopsies were fixed by incubation for $24 \mathrm{~h}$ in $4 \%$ paraformaldehyde, $1 \%$ glutaraldehyde in $0.1 \mathrm{M}$ phosphate buffer ( $\mathrm{pH}$ 7.2). Samples were then washed in phosphate-buffered saline (PBS) and post-fixed by incubation with $2 \%$ osmium tetroxide for $1 \mathrm{~h}$. Samples were then fully dehydrated in a graded series of ethanol solutions followed by a propylene oxide bath. Pre-impregnation step was made by a propylene oxyde/Epon resin mixture (Sigma) and finally overnight in pure resin for impregnation of the samples. Cells were then embedded in Epon resin (Sigma), which was allowed to polymerize for $48 \mathrm{~h}$ at $60^{\circ} \mathrm{C}$. Ultra-thin sections $(90 \mathrm{~nm})$ of these blocks were obtained with a Leica EM UC7 ultramicrotome (Wetzlar, Germany). Sections were deposited on gold grids and stained with $2 \%$ uranyl acetate, 5\% lead citrate. Observations were made with a JEOL 1011 transmission electron microscope. Images were analysed using ImageJ software (NIH)

\section{Phospholipid classes quantitation}

Mitochondria were extracted from HepaRG cells by differential centrifugation. Then mitochondrial lipids were extracted following the protocol of Bligh and Dyer [24]. In order to quantify mitochondrial phospholipids (cardiolipin $[\mathrm{CL}]$, phosphatidylethanolamine $[\mathrm{PE}]$, phosphatidylinositol $[\mathrm{PI}]$, phosphatidylcholine [PC], phosphatidylserine [PS] and sphyngomyelin [SM]), standards and samples were loaded on silica plates using Linomat V sample applicator (CAMAG, Muttenz Switzerland). Solvant consisted of chloroform, acetone, acetic acid methanol and water (6/8/2/2/1 v/v/v/v/v) modified from [25]. After migration, the plates were immersed into the following solution $(10 \% \mathrm{wt} / \mathrm{vol})$ copper sulfate in $8 \%$ (vol/vol) phosphoric acid solution) and then heated at $160^{\circ} \mathrm{C}$ for $15 \mathrm{~min}$ to stain all of the phospholipids. Quantification was performed using Thin Layer Chromatography-visualizer Reprostar $3^{\circledR}$ and WinCats 
VideoScan ${ }^{\circledR}$ software (CAMAG, Muttenz Switzerland). Results were expressed in percent of total mitochondrial phospholipids.

\section{CL fatty acid molecular species Analysis by $L C-M S^{2}$}

Lipids were extracted from cell pellets (6-8 millions) according to the method of Folch et al. [26].

In brief, cells were spiked with (14:0)4-CL used as internal standard (250 ng, Avanti Polar Lipids, Coger, Paris, France). Lipids were extracted with $1 \mathrm{~mL}$ of saline and $3.5 \mathrm{~mL}$ of $\mathrm{CHCl} / \mathrm{MeOH}(2 / 1)$ for $10 \mathrm{~min}$ followed by addition of $1.25 \mathrm{~mL} \mathrm{CHCl} 3$ for $10 \mathrm{~min}$ and finally $1.25 \mathrm{~mL}$ of distilled water for $5 \mathrm{~min}$. Organic phase was collected and dried under vacuum. Lipid extracts were further solubilized in $100 \mu \mathrm{L}$ of $\mathrm{CHCl3} / \mathrm{MeOH} / \mathrm{H} 2 \mathrm{O}(60 / 30 / 4.5)$. LCMS/MS analyses were performed with a 1200 series HPLC system coupled to a 6460 triple quadrupole mass spectrometer equiped with a JetStream electrospray ionization source (Agilent Technologies). HPLC separation was achieved with a Zorbax EclipsePlus C18 - $2.1 \mathrm{~mm}$ x $100 \mathrm{~mm}, 1.8 \mu \mathrm{m}$ column (Agilent Technologies) maintained at $50^{\circ} \mathrm{C}$. The mobile phases consisted of ACN, water, $28 \% \mathrm{NH} 3$ in water and acetic acid (90/10/0.2/0.5 v/v/v/v) (A) and of IPA, water, $28 \% \mathrm{NH} 3$ in water and acetic acid (90/10/0.2/0.5 v/v/v/v) (B). The linear gradient was as follows: $50 \%$ B for 5 min, up to $80 \% \mathrm{~B}$ in $10 \mathrm{~min}$, up to $100 \%$ in $15 \mathrm{~min}$ and maintained at $100 \%$ for $5 \mathrm{~min}$. Column was equilibrated with $50 \%$ B for $5 \mathrm{~min}$ before each injection. The flow rate was set up at $0.4 \mathrm{~mL} / \mathrm{min}$. Four microliters were injected onto the LCMS/MS system. Analyses were performed in negative ion mode by Selected Reaction Monitoring (SRM) as previously described [27].

\section{RNA isolation and real time PCR assay}

Total RNA from livers or HepaRG cells were extracted with RNeasy Mini kit (QIAGEN; Cat N 74106) following manufacturer's instructions. Reverse transcription was performed using $1 \mu \mathrm{g}$ of total ARN with the High Capacity cDNA Reverse Transcription kit (Applied Biosystems, Part N 4368813). RNA levels of various genes were determined using Taqman- (HepaRG cells) or SYBR green (rat liver)-based quantitative PCR (qPCR) technology performed using Fast Real-time 7900HT system (Applied Biosystems). The $18 \mathrm{~S}$ and GAPDH were used as housekeeping genes for rat livers and HepaRG cells, respectively. Data were quantified with the StepOne Plus software v2.2.1 and the results were expressed as relative to pair-fed animals or untreated HepaRG cultures arbitrarily set to 1 . Primer sequences: rat $18 \mathrm{~S}$ 
5'-CGGCTACCACATCCAAGGAA -3' and 5'- GCTGGAATTACCGCGGCT-3', rat CDS1 5'GACTCCAGAACACTGTATCT-3' and 5'- GCTCACAGCAGCAATTTGAT-3', rat PGPS 5'GGCAGATAAAAATAGCCAAG-3' and 5'- CAATCCACCAGTTCCTGTTCC-3', rat CLS 5'GAACACTAGCTAAGTACTTC-3' and 5'- ACTGCTGTATTGACCTTGC-3', rat TAZ 5'CTGAAGTTGATGCGTTGGACC-3' and 5'- TGTACCCAGTCCCCATGGTT-3'. Taqman primers for human GAPDH Hs02758991_g1, human PGPP Hs00864157_g1, human PGPS Hs00375485_m1, human CLS Hs00219512_m1, human MLCL AT-1 Hs00426191_m1, human TAZ Hs00794094_m1, human human ALB (Hs00910225_m1) and human TATA Binding Protein (TBP) (Hs00427620_m1).

\section{Western blotting}

Rat liver and HepaRG cell mitochondria were isolated as described [28]. $50 \mu \mathrm{g}$ of mitochondrial protein were separated on $12 \%$ sodium dodecyl sulfate-polyacrylamide gel electrophoresis, transferred onto a polyvinylidene fluoride membrane, and probed with antibodies against CLS (14845-1-AP, Proteintech, Manchester, UK), Heat shock cognate 70 (Hsc70, SC7298, SantaCruz) and Voltage Dependent anion channels (VDAC) (AB14734 Abcam) (loading control) followed by horseradish peroxidase-coupled detection (Pierce ECL Western Blotting Substrate). Secondary antibodies were obtained from SantaCruz. The protein band intensities were analyzed by densitometry (MF-ChemiBIS 3.2, DNR Bioimaging Systems, MultiGauge software, Fujifilm).

\section{Assay of enzyme activities}

Rat liver and HepaRG cell mitochondria were isolated as described [28]. CDS, PGPS enzyme activities were determined as described [22]. CL synthase activity was assayed exactly as described by Schlame and Hostetler [29], except that the assay contained $0.05-0.1 \mathrm{mg}$ of protein, the $\mathrm{pH}$ of the assay was 8.5 and the samples were sonicated for $10 \mathrm{~s}$ in a Branson model 1200 sonicator before incubation. Incubation was at $37^{\circ} \mathrm{C}$ for $60 \mathrm{~min}$ with [14C]PG (sp.radioactivity 45000 d.p.m./nmol). MLCL AT-1 activity was determined as described [30].

\section{High-resolution respirometry}


High resolution respirometry was performed using a 2-ml chamber OROBOROS ${ }^{\circledR}$ Oxygraph $2 \mathrm{~K}$ (Oroboros Instruments, Innsbruck, Austria) at $37^{\circ} \mathrm{C}$. Respiration rates were calculated as the time derivative of oxygen concentration measured in the closed respirometer and expressed per million viable cells and corrected by non-mitochondrial oxygen consumption (antimycin A). Intact cells $\left(0.5 \times 10^{6}\right.$ cells per milliliter) were analyzed in their respective energy substrate-containing cultivation medium: ROUTINE respiration (no additions), LEAK respiration (oligomycin-inhibited, $8 \mu \mathrm{g} / \mathrm{mL}$ ), and ETS (Electron Transfert System) capacity (maximum uncoupled respiration) induced by Carbonyl cyanide-4(trifluoromethoxy)phenylhydrazone (FCCP, $0.8 \mathrm{mM})$. Oxygen consumption $\left(\mathrm{O}_{2}\right)$ was also measured on permeabilized cells (digitonin $11 \mu \mathrm{g} / \mathrm{ml})$ in respiration buffer $\left(10 \mathrm{mM} \mathrm{KH}_{2} \mathrm{PO}_{4}, 300 \mathrm{mM}\right.$ mannitol, $10 \mathrm{mM}$ $\mathrm{KCl}, 5 \mathrm{mM} \mathrm{MgCl} \mathrm{m}_{2}, 1 \mathrm{mM} \mathrm{EGTA}$ and $1 \mathrm{mg} / \mathrm{ml} \mathrm{BSA}$ fatty acid free) at final cell density of $0.5 \times 10^{6}$ cells per milliliter. Pyruvate, malate and succinate were used as respiratory substrates.

\section{Statistical analysis}

Data are expressed as means \pm S.E.M. Statistical analyses were performed using GraphPad Prism ${ }^{\circledR}$. The differences between two groups were evaluated by non parametric Mann Whitney $t$-test. Values showing $p$ $<0.05$ were considered statistically significant unless otherwise indicated. 


\section{RESULTS}

\section{Mitochondrial content is unchanged during cancer cachexia}

$\mathrm{CL}$ is a unique phospholipid only found in mitochondrial membranes. In order to exclude that mitochondrial biogenesis was the origin for CL accumulation $(+50 \%)$; we first quantified liver mitochondrial mass from PF and PCC rats using electron microscopy. Our results did not show any difference between the two groups of rats (Figure 1). Indeed, hepatocytes from PF rats contained 20.32\% +/- 1.95 of mitochondria whereas $22.24 \%+/-1.58$ for PCC rat hepatocytes.

\section{Liver PGPS and CLS are altered in cancer cachexia}

To investigate the biochemical alterations in CL biosynthesis during cancer cachexia four enzymes of CL metabolism were studied: CDS-1, PGPS, PGPP, and CLS in liver of healthy (PF) and cachectic rats (PCC). CDS-1 mRNA level and CDS enzyme activity were similar between PCC and PF rats (Figure 2A and B). In contrast, gene expression of PGPS was significantly increased by 2.3 -fold $(p=0.02)$ in liver of PCC compared to PF rats (Figure 2C). In addition, PGPS activity appeared to be increased by $30 \%$ in PCC compared to PF rats (Figure 2D) without reaching statistical significance. PGPP mRNA expression was unaltered between PCC and PF rats $(0.56+/-0.20$ and $0.63+/-0.14$, respectively). CLS mRNA and protein expression were similar between PCC and PF rats (Figure $3 \mathrm{~A}$ and B). However, mitochondrial CLS enzyme activity was significantly decreased by $44 \%$ in PCC rats $(p=0.03)$ compared to PF rats (Figure $3 \mathrm{C}$ ).

\section{Liver CL remodeling processes are affected by cancer cachexia}

We previously reported important modifications in CL fatty acid composition in liver mitochondria from cachectic rats [7] suggesting a modulation in CL remodeling. We examined four enzymes implicated in this process: iPLA2 $\gamma$, MLCL AT-1, ALCAT1 and TAZ in livers of healthy (PF) and cachectic rats (PCC). iPLA2 $\gamma$ enzyme activity and mRNA expression were not different from PCC and PF rats (mRNA: 0.64 +/0.25 vs $0.88+/-0.30$ and activity: $767+/-160$ vs $823+/-46 \mathrm{pmol} \cdot \mathrm{mg}^{-1} \cdot \mathrm{min}^{-1}$, respectively). In addition 
MLCL AT-1 enzyme activity was significantly increased by $30 \%$ in PCC rat liver mitochondria compared to PF rats $(p=0.01)$ (Figure $3 \mathrm{D})$. ALCAT1 mRNA expression was similar in liver between PCC and PF rats $(1.24+/-0.28$ vs $1.27+/-0.19$, respectively). Finally, TAZ mRNA expression was significantly increased (50\%) in PCC rats compared to PF rats $(p=0.02)$ (Figure $3 \mathrm{E}$ ).

\section{TNFa treatment increases specifically hepatocyte CL content without changes in mitochondrial mass}

Since TNF $\alpha$ was elevated 14 -fold in plasma in rat model of peritoneal carcinosis induced cancer cachexia, the effect of exogenous TNF $\alpha$ addition to HepaRG cells on CL metabolism was examined. Incubation of HepaRG cells with TNF $\alpha$ resulted in a significant $15 \%(\mathrm{p}<0.05)$ increase in CL content compared to controls (Figure 4 A). In contrast, PE, PI, PC+PS and SM content did not differ between control cells and TNF $\alpha$ treated cells. In order to confirm that CL accumulation in response to TNF $\alpha$ was not due to an increase in mitochondrial mass, we quantified mitochondria area and number per cell area using transmission electron microscopy (Figure $4 \mathrm{~B}, \mathrm{C}$ and D). Our result clearly demonstrated that TNF $\alpha$ has no effect on mitochondrial content (Control: $10.12 \%+/-0.33$, TNF $\alpha$ : $10.26 \%+/-0.30$ mitochondrial area $\%$ of cell area).

\section{TNFa treatment alters HepaRG mitochondrial bioenergetics}

Since CL plays a role in cellular energy metabolism and CL content was elevated in HepaRG cells treated with $\mathrm{TNF} \alpha$, we examined oxygen consumption in these cells. In intact HepaRG cells TNF $\alpha$ induced an overall increase in $\mathrm{O}_{2}$ consumption (Figure 5). In fact, under routine conditions (cells using their own substrates in an energetic state with ATP production as a function of the energy needs of the cells) $\mathrm{O}_{2}$ consumption was $33 \%$ higher in cells incubated with TNF $\alpha$ compared to control cells (figure $5 \mathrm{~A}$ ). In the non-phosphorylating state, $\mathrm{O}_{2}$ consumption (reflecting energy leak) in the presence of oligomycin, was significantly increased by $57 \%$ in cells treated with $\mathrm{TNF} \alpha$ compared to controls. TNF $\alpha$ induced a significant $53 \%$ increase in maximal $\mathrm{O}_{2}$ consumption (uncoupled state, electron transport chain maximal capacities ETS) compared to controls (figure 5A). When cells were permeabilized, we observed globally the same effect of $\mathrm{TNF} \alpha$ on mitochondrial bioenergetics using pyruvate, malate and succinate as 
substrates (Figure $5 \mathrm{~B}$ ). $\mathrm{O}_{2}$ consumption in non-phosphorylating (state 4) was significantly increased $33 \%$ in TNF $\alpha$-treated cells compared to control cells (figure 5B). In the phosphorylating state (state 3), TNF $\alpha$ treated cells had a $17 \%$ significant increase in $\mathrm{O}_{2}$ consumption compared to controls. Finally, uncoupled state related- $\mathrm{O}_{2}$ consumption was increased $14 \%$ with TNF $\alpha$ compared to controls, however, this did not reach statistical significance (figure $5 \mathrm{~B}$ ).

\section{TNFa treatment increases PGPS gene expression in HepaRG cells}

We examined the mechanism for the increase in CL in TNF $\alpha$-treated cells. Incubation of HepaRG cells with TNF $\alpha$ did not affect mRNA expression of PGPP or CLS compared to controls (Figure 6 A and C). In contrast, PGPS mRNA expression was significantly increased $44 \%$ in cells incubated with TNF $\alpha$ compared to controls (Figure 6 B). Interestingly, incubation of HepaRG cells with TNF $\alpha$ did not affect TAZ, MLCL AT-1 or ALCAT1 mRNA expression (Figure 6 D, E and F). In addition, incubation of HepaRG cells with TNF $\alpha$ did not affect enzyme activities of CDS, PGPS and CLS compared to controls (Figure 7 A, B and C). In contrast, MLCL AT-1 activity was significantly increased 20\% in cells treated with TNF $\alpha$ compared to controls (Figure $7 \mathrm{D}$ ).

\section{TNFa treatment alters CL fatty acid molecular species in HepaRG cells}

Next we asked if TNF $\alpha$ induced increase in MLCL AT-1 activity was associated to modification in CL molecular species. In fact, CL molecular species (18:1) ${ }_{3}-(18: 2)$ and $(18: 2)_{3}-(16: 1)$, have significantly altered content, respectively $+15 \%$ and $-10 \%$, in $\mathrm{TNF} \alpha$ treated hepatocytes compared to controls (Figure 8). Furthermore (16:0)-(18:1) $)_{2}-(18: 2)$ and (18:1) $)_{4}$ content was increased by $17 \%$ and $20 \%$ in HepaRG cells incubated with $\mathrm{TNF} \alpha$, without reaching statistical significance $(\mathrm{p}=0.08)$ (Figure 8).

\section{TNFa increases CL content by PGPS upregulation in HepaRG cells}

Next we tested the direct connection between TNF $\alpha$, CL content and PGPS expression. PGPS expression in siPGPS HepaRG cells was significantly reduced by $63 \%$ in comparison of siALB cells $(0,37+/-0,07$ 
vs $1.00+/-0.11$, relative expression/TBP respectively, $\mathrm{N}=4, \mathrm{p}=0.028$ ). Moreover, CL content was not affected by TNF $\alpha$ in siPGPS cells compared to controls (figure 9). 


\section{DISCUSSION}

The aim of the present study was to investigate the mechanisms responsible for liver mitochondrial CL accumulation and alteration of CL fatty acyl composition in a preclinical model of cancer cachexia. For this purpose, we examined gene and protein expression and activities of the main enzymes involved in CL biosynthesis and remodeling in liver mitochondria using a preclinical model of cancer cachexia. In addition, we investigated in vitro the effect of the proinflammatory cytokine TNFa, a hallmark of cancer cachexia, on CL content and the CL metabolic enzymes in HepaRG hepatocyte like cells.

We observed discordant regulation of CL biosynthetic and remodeling enzymes at both the activity and gene expression level in liver mitochondria of cachectic rats compared to controls. We found that gene expression of PGPS and TAZ were significantly increased and that enzyme activities of PGPS (statistical trend -30\%) and MLCL AT-1 were increased and enzyme activity of CLS decreased in liver from cancer cachexia rats. PGPS catalyzes the committed step of CL biosynthesis [14]. The observed elevated mRNA expression and activity of PGPS in livers of PCC rats might increase precursor supply for CL de novo synthesis. A previous study showed increased liver CL pool size was associated with an increased expression and activity of PGPS during rat liver regeneration [31]. Moreover, the importance of PGPS in controlling CL level was previously demonstrated in Chinese hamster ovary (CHO) cells [32]. In that study, a temperature sensitive CHO cell line defective in PGPS exhibited reduced cellular levels of CL. CLS mRNA and protein expression were unaltered in liver of PCC rats compared to PF rats. Surprisingly, CLS enzyme activity was reduced approximately 50\% in liver mitochondria of PCC rats compared to PF rats. The observed decrease in CLS activity could be a compensatory mechanism to counteract the increased CL formed in liver of PCC rats. We previously showed that CLS mRNA expression does not correlate with endogenous CLS enzyme activity [33]. In Micrococcus lysodeikticus the end-product of CL synthesis, CL, was shown to inhibit CLS at several concentrations [34]. In addition, in rat liver mitochondria exogenous addition of CL was shown to markedly inhibit CLS activity [35]. Since CL levels were elevated in liver mitochondria of cachectic rats this would explain why CLS enzyme activity was reduced. Thus, although CLS activity was decreased by a higher level of CL, the elevated 
mRNA expression of PGPS could lead to an increase in precursor synthesis for increased CL de novo biosynthesis provoking CL accumulation in livers of cachectic rats. These data represent the first direct demonstration of dysregulation of CL biosynthesis in cancer cachexia.

We previously observed a lower $n-6 / n-3$ polyunsaturated fatty acid ratio in CL in liver mitochondria prepared from cancer cachectic rats [7]. Liver CL is enriched with linoleic acid and this polyunsaturated fatty acid enrichment of CL can be achieved by a CL transacylase encoded by the Taz gene [36] or by transfer of linoleoyl-CoA to MLCL by MLCL AT-1 [37]. Gene expression of ALCAT1, an enzyme capable of acylating MLCL with polyunsaturated species of fatty acid to form polyunsaturated fatty acid enriched CL [15], was unaltered in liver of PCC rats compared to PF rats. In addition, the activity of iPLA2 $\gamma$, an enzyme known to deacylate CL [13], was unaltered in PCC rats compared to PF rats. In contrast, we observed a significant increase in both MLCL AT-1 enzyme activity and in TAZ mRNA expression. This increase in TAZ expression and MLCL AT-1 enzyme activity in liver of PCC rats was likely responsible for the altered fatty acid profile of CL observed in liver cachexia compared to control animals [7].

Since inflammation is a hallmark of cancer cachexia [20], we investigated the potential role of inflammatory cytokines in CL related-mitochondrial bioenergetics alterations in HepaRG hepatocytes. We previously identified TNF $\alpha$ as a major cytokine in our preclinical model of cancer cachexia [6]. In addition, an increased expression of $\mathrm{TNF} \alpha$ has been observed in liver of cancer cachectic rats [38]. Therefore we examined in vitro the effects of TNF $\alpha$ treatment on HepaRG cell CL metabolism. Incubation with TNF $\alpha$ for $12 \mathrm{~h}$ increased mitochondrial CL content by $15 \%$ in HepaRG cells without affecting the level of other phospholipids. This increase in CL content was not related to an increase in mitochondrial mass in the cells treated with TNF $\alpha$. We subsequently explored whether this increase in CL content in HepaRG cell mitochondria, mediated by $\mathrm{TNF} \alpha$, was associated with modification in mitochondrial bioenergetics. TNF $\alpha$-treatment resulted in a significant increase in oxygen consumption in different energy states. The effect of TNF $\alpha$ on mitochondrial bioenergetics is subject to debate. Previous studies reported that TNF $\alpha$ treated cells exhibited inhibition of respiratory chain activity leading to enhanced superoxide production and apoptosis [39-42]. In contrast, other studies have demonstrated an increase in 
mitochondrial oxygen consumption in TNF $\alpha$ treated cells [43-45]. This discrepancy highlights the fact that $\mathrm{TNF} \alpha$-mediated effects are very much dependent on cell type, cytokine concentration and treatment duration making comparison between studies difficult. However, our results are in agreement with recently published data by Drabarek and collaborators [44] in that our experimental protocol closely resembled their experimental conditions (hepatocyte cells, short term exposure and low TNF $\alpha$ concentration). Since mitochondrial biogenesis markers PGC-1 $\alpha$ and mitochondrial transcription factor A protein expression were unaffected by $\mathrm{TNF} \alpha$ treatment (data not shown), the increase in oxygen consumption by $30-40 \%$ (depending of cell configuration) in the non-phosphorylating state was clearly an indication for an increase in energy wasting. Furthermore, we previously demonstrated that in cancer cachexia, CL content of rat liver biopsies are increased and positively correlated to energy wasting in mitochondria [7]. Moreover, we successfully reproduced in vitro this effect by mitochondrial membrane CL enrichment demonstrating a direct link between CL content and oxidative phosphorylation efficiency [8]. Taken together, all of these results indicate that $\mathrm{TNF} \alpha$ may induce increase energy wasting in hepatocytes in vivo by increasing CL content.

Since in vitro treatment of HepaRG cells with TNF $\alpha$ increased CL content and energy wasting similar to what we previously observed in cachectic rat liver biopsies [7], we postulated that TNF $\alpha$ signaling regulated specifically PGPS gene expression in cancer cachexia and resulting in the increase in CL. Previously we showed that incubation of H9c2 cells with TNF $\alpha$ induced an increase in PGPS [46]. Thus, we investigated if TNF $\alpha$ regulated gene expression of PGPS and other CL metabolism related enzymes in HepaRG cells. A $12 \mathrm{~h}$ treatment of HepaRG cells with TNF $\alpha$ resulted in an increase in PGPS gene expression and an increase in MLCL AT-1 activity. These data are in agreement with previous published data demonstrating a TNF $\alpha$ induced-PGPS overexpression in cardiomyocyte cell line [46]. Moreover we had previously shown that MLCL AT-1 activity is regulated in concert with the level of CL and CL biosynthesis in rat heart [47]. The observed increase in MLCL AT-1 activity after treatment of HepaRG cells with TNFa is likely required to support elevated CL remodeling with increased CL synthesis. In support of this were the observed alterations in CL fatty acid molecular species composition. 


\section{ACCEPTED MANUSCRIPT}

Finally, the absence of modification in CL content in siRNA PGPS-transfected HepaRG cells exposed to TNF $\alpha$ highlighted that action of TNF $\alpha$ on CL content is mediated by PGPS.

In conclusion, this is the first study that demonstrates alteration in liver CL metabolism related enzymes in cancer cachexia. In addition, our data clearly demonstrate that TNF $\alpha$ treatment increases CL content in hepatocytes. These data strongly suggest that in cancer cachexia, TNF $\alpha$ is one of the factors responsible for inducing the increase in energy wasting in liver mitochondria by increasing CL content through upregulation of PGPS expression. 


\section{Acknowledgements}

This paper is dedicated to the memory of William A. Taylor who passed away prematurely during this study. This work was funded by "Ligue contre le Cancer" (16, 18, 37, 72 and 85 committees), Région Centre (LIPIDS project of ARD2020-Biomedicaments), "Cancéropole Grand Ouest", "Groupe Lipides Nutrition" and "Association CANCEN". Laure Peyta received a fellowship from"Ministère de l'Enseignement Supérieur et de la Recherche ». We thank Fred Xu for PGPS enzyme activity assays. This work was supported by grants from the CIHR and Heart and Stroke Foundation of Canada (G.M.H.). G.M.H. is a Canada Research Chair in Molecular Cardiolipin Metabolism. 


\section{References}

[1] K. Fearon, F. Strasser, S.D. Anker, I. Bosaeus, E. Bruera, R.L. Fainsinger, et al., Definition and classification of cancer cachexia: an international consensus, Lancet Oncol. 12 (2011) 489-495. doi:10.1016/S1470-2045(10)70218-7.

[2] W.D. Dewys, C. Begg, P.T. Lavin, P.R. Band, J.M. Bennett, J.R. Bertino, et al., Prognostic effect of weight loss prior to chemotherapy in cancer patients. Eastern Cooperative Oncology Group, Am J Med. 69 (1980) 491-497.

[3] A. Laviano, M.M. Meguid, A. Inui, M. Muscaritoli, F. Rossi-Fanelli, Therapy insight: Cancer anorexia-cachexia syndrome--when all you can eat is yourself, Nat Clin Pr. Oncol. 2 (2005) 158165. doi:10.1038/ncponc0112.

[4] M. Pressoir, S. Desné, D. Berchery, G. Rossignol, B. Poiree, M. Meslier, et al., Prevalence, risk factors and clinical implications of malnutrition in French Comprehensive Cancer Centres., Br. J. Cancer. 102 (2010) 966-971. doi:10.1038/sj.bjc.6605578.

[5] C.M. Prado, S. Antoun, M.B. Sawyer, V.E. Baracos, Two faces of drug therapy in cancer: drugrelated lean tissue loss and its adverse consequences to survival and toxicity., Curr. Opin. Clin. Nutr. Metab. Care. 14 (2011) 250-4. doi:10.1097/MCO.0b013e3283455d45.

[6] J.-F. Dumas, C. Goupille, M. Pinault, L. Fandeur, P. Bougnoux, S. Servais, et al., n-3 PUFAenriched diet delays the occurrence of cancer cachexia in rat with peritoneal carcinosis, Nutr Cancer. 62 (2010) 343-350. doi:10.1080/01635580903407080.

[7] J.-F. Dumas, C. Goupille, C.M. Julienne, M. Pinault, S. Chevalier, P. Bougnoux, et al., Efficiency of oxidative phosphorylation in liver mitochondria is decreased in a rat model of peritoneal carcinosis, J Hepatol. 54 (2011) 320-327. doi:10.1016/j.jhep.2010.08.012.

[8] C.M. Julienne, M. Tardieu, S. Chevalier, M. Pinault, P. Bougnoux, F. Labarthe, et al., Cardiolipin content is involved in liver mitochondrial energy wasting associated with cancer-induced cachexia without the involvement of adenine nucleotide translocase., Biochim. Biophys. Acta. 1842 (2014) 726-33. doi:10.1016/j.bbadis.2014.02.003.

[9] J. Lecoq, C. Ballou, On the structure of cardiolipin., Biochemistry. 3 (1964) 976-80.

[10] G. Paradies, V. Paradies, V. De Benedictis, F.M. Ruggiero, G. Petrosillo, Functional role of cardiolipin in mitochondrial bioenergetics., Biochim. Biophys. Acta. 1837 (2014) 408-17. doi:10.1016/j.bbabio.2013.10.006.

[11] J. Zhang, Z. Guan, A.N. Murphy, S.E. Wiley, G.A. Perkins, C. a Worby, et al., Mitochondrial phosphatase PTPMT1 is essential for cardiolipin biosynthesis., Cell Metab. 13 (2011) 690-700. doi:10.1016/j.cmet.2011.04.007.

[12] B. Lu, F.Y. Xu, Y.J. Jiang, P.C. Choy, G.M. Hatch, C. Grunfeld, et al., Cloning and characterization of a cDNA encoding human cardiolipin synthase (hCLS1)., J. Lipid Res. 47 (2006) 1140-5. doi:10.1194/jlr.C600004-JLR200. 
[13] Y.-H. Hsu, D.S. Dumlao, J. Cao, E.A. Dennis, Assessing phospholipase A2 activity toward cardiolipin by mass spectrometry., PLoS One. 8 (2013) e59267.

doi:10.1371/journal.pone.0059267.

[14] E.M. Mejia, L.K. Cole, G.M. Hatch, Cardiolipin metabolism and the role it plays in heart failure and mitochondrial supercomplex formation., Cardiovasc. Hematol. Disord. Drug Targets. 14 (2014) 98-106.

[15] J. Cao, Y. Liu, J. Lockwood, P. Burn, Y. Shi, A novel cardiolipin-remodeling pathway revealed by a gene encoding an endoplasmic reticulum-associated acyl-CoA:lysocardiolipin acyltransferase (ALCAT1) in mouse., J. Biol. Chem. 279 (2004) 31727-34. doi:10.1074/jbc.M402930200.

[16] M. Ren, C.K.L. Phoon, M. Schlame, Metabolism and function of mitochondrial cardiolipin., Prog. Lipid Res. 55 (2014) 1-16. doi:10.1016/j.plipres.2014.04.001.

[17] M.G. Baile, Y.-W. Lu, S.M. Claypool, The topology and regulation of cardiolipin biosynthesis and remodeling in yeast., Chem. Phys. Lipids. 179 (2014) 25-31.

doi:10.1016/j.chemphyslip.2013.10.008.

[18] Y.J. Jiang, B. Lu, F.Y. Xu, J. Gartshore, W.A. Taylor, A.J. Halayko, et al., Stimulation of cardiac cardiolipin biosynthesis by PPARalpha activation, J Lipid Res. 45 (2004) 244-252. doi:10.1194/jlr.M300314-JLR200.

[19] L. Lai, M. Wang, O.J. Martin, T.C. Leone, R.B. Vega, X. Han, et al., A role for peroxisome proliferator-activated receptor $\gamma$ coactivator 1 (PGC-1) in the regulation of cardiac mitochondrial phospholipid biosynthesis., J. Biol. Chem. 289 (2014) 2250-9. doi:10.1074/jbc.M113.523654.

[20] J.K. Onesti, D.C. Guttridge, Inflammation based regulation of cancer cachexia., Biomed Res. Int. 2014 (2014) 168407. doi:10.1155/2014/168407.

[21] P. Gripon, S. Rumin, S. Urban, J. Le Seyec, D. Glaise, I. Cannie, et al., Infection of a human hepatoma cell line by hepatitis B virus., Proc. Natl. Acad. Sci. U. S. A. 99 (2002) 15655-60. doi:10.1073/pnas.232137699.

[22] G.M. Hatch, G. McClarty, Regulation of cardiolipin biosynthesis in H9c2 cardiac myoblasts by cytidine 5'-triphosphate., J. Biol. Chem. 271 (1996) 25810-6.

[23] V. Laurent, A. Fraix, T. Montier, S. Cammas-Marion, C. Ribault, T. Benvegnu, et al., Highly efficient gene transfer into hepatocyte-like HepaRG cells: New means for drug metabolism and toxicity studies, Biotechnol. J. 5 (2010) 314-320. doi:10.1002/biot.200900255.

[24] E.G. Bligh, W.J. Dyer, A rapid method of total lipid extraction and purification., Can. J. Biochem. Physiol. 37 (1959) 911-7.

[25] M. Arvier, L. Lagoutte, G. Johnson, J.F. Dumas, B. Sion, G. Grizard, et al., Adenine nucleotide translocator promotes oxidative phosphorylation and mild uncoupling in mitochondria after dexamethasone treatment, Am J Physiol Endocrinol Metab. 293 (2007) E1320-4.

[26] J. Folch, M. Lees, G.H. Sloane Stanley, A simple method for the isolation and purification of total lipides from animal tissues., J. Biol. Chem. 226 (1957) 497-509. 
[27] G. Vial, M.-A. Chauvin, N. Bendridi, A. Durand, E. Meugnier, A.-M. Madec, et al., Imeglimin Normalizes Glucose Tolerance and Insulin Sensitivity and Improves Mitochondrial Function in Liver of a High-Fat High-Sucrose Diet Mice Model., Diabetes. (2014). doi:10.2337/db14-1220.

[28] W.A. Taylor, G.M. Hatch, Purification and characterization of monolysocardiolipin acyltransferase from pig liver mitochondria., J. Biol. Chem. 278 (2003) 12716-21. doi:10.1074/jbc.M210329200.

[29] M. Schlame, K.Y. Hostetler, Mammalian cardiolipin biosynthesis., Methods Enzymol. 209 (1992) $330-7$.

[30] W. a Taylor, G.M. Hatch, Identification of the human mitochondrial linoleoyl-coenzyme A monolysocardiolipin acyltransferase (MLCL AT-1)., J. Biol. Chem. 284 (2009) 30360-71. doi:10.1074/jbc.M109.048322.

[31] J. Webster, J.Y. Jiang, B. Lu, F.Y. Xu, W.A. Taylor, M. Mymin, et al., On the mechanism of the increase in cardiolipin biosynthesis and resynthesis in hepatocytes during rat liver regeneration., Biochem. J. 386 (2005) 137-43. doi:10.1042/BJ20040655.

[32] T. Ohtsuka, M. Nishijima, Y. Akamatsu, A somatic cell mutant defective in phosphatidylglycerophosphate synthase, with impaired phosphatidylglycerol and cardiolipin biosynthesis., J. Biol. Chem. 268 (1993) 22908-13.

[33] B. Lu, F.Y. Xu, W. a Taylor, K.R. Feingold, G.M. Hatch, Cardiolipin synthase-1 mRNA expression does not correlate with endogenous cardiolipin synthase enzyme activity in vitro and in vivo in mammalian lipopolysaccharide models of inflammation., Inflammation. 34 (2011) 247-54. doi:10.1007/s10753-010-9230-3.

[34] A.J. De Siervo, Inhibition of cardiolipin synthesis by end-products and other complex lipids in membrane preparations of Micrococcus lysodeikticus., Can. J. Biochem. 53 (1975) 1031-4.

[35] W.C. McMurray, E.C. Jarvis, Partial purification of diphosphatidylglycerol synthetase from liver mitochondrial membranes., Can. J. Biochem. 58 (1980) 771-6.

[36] S. Bione, P. D'Adamo, E. Maestrini, A.K. Gedeon, P.A. Bolhuis, D. Toniolo, A novel X-linked gene, G4.5. is responsible for Barth syndrome., Nat. Genet. 12 (1996) 385-9. doi:10.1038/ng0496385 .

[37] B.J. Ma, W.A. Taylor, V.W. Dolinsky, G.M. Hatch, Acylation of monolysocardiolipin in rat heart., J. Lipid Res. 40 (1999) 1837-45.

[38] M.G. Catalano, N. Fortunati, K. Arena, P. Costelli, M. Aragno, O. Danni, et al., Selective upregulation of tumor necrosis factor receptor I in tumor-bearing rats with cancer-related cachexia., Int. J. Oncol. 23 (2003) 429-36.

[39] S. Djafarzadeh, M. Vuda, J. Takala, S.M. Jakob, Effect of remifentanil on mitochondrial oxygen consumption of cultured human hepatocytes., PLoS One. 7 (2012) e45195. doi:10.1371/journal.pone.0045195.

[40] R. Zell, P. Geck, K. Werdan, P. Boekstegers, TNF-alpha and IL-1 alpha inhibit both pyruvate dehydrogenase activity and mitochondrial function in cardiomyocytes: evidence for primary impairment of mitochondrial function., Mol. Cell. Biochem. 177 (1997) 61-7. 
[41] J. Stadler, B.G. Bentz, B.G. Harbrecht, M. Di Silvio, R.D. Curran, T.R. Billiar, et al., Tumor necrosis factor alpha inhibits hepatocyte mitochondrial respiration., Ann. Surg. 216 (1992) 539-46.

[42] J.R. Lancaster Jr., S.M. Laster, L.R. Gooding, J.R. Lancaster, Inhibition of target cell mitochondrial electron transfer by tumor necrosis factor, FEBS Lett. 248 (1989) 169-174.

[43] L. Kastl, S.W. Sauer, T. Ruppert, T. Beissbarth, M.S. Becker, D. Süss, et al., TNF- $\alpha$ mediates mitochondrial uncoupling and enhances ROS-dependent cell migration via NF- $\mathrm{kB}$ activation in liver cells., FEBS Lett. 588 (2014) 175-83. doi:10.1016/j.febslet.2013.11.033.

[44] B. Drabarek, D. Dymkowska, J. Szczepanowska, K. Zabłocki, TNF $\alpha$ affects energy metabolism and stimulates biogenesis of mitochondria in EA.hy926 endothelial cells., Int. J. Biochem. Cell Biol. 44 (2012) 1390-7. doi:10.1016/j.biocel.2012.05.022.

[45] S. Busquets, X. Aranda, M. Ribas-Carbó, J. Azcon-Bieto, F.J. López-Soriano, J.M. Argilés, et al., Tumour necrosis factor-alpha uncouples respiration in isolated rat mitochondria, Cytokine. 22 (2003) $1-4$.

[46] F.Y. Xu, S.L. Kelly, G.M. Hatch, N-Acetylsphingosine stimulates phosphatidylglycerolphosphate synthase activity in H9c2 cardiac cells., Biochem. J. 337 (1999) 483-90.

[47] W. a Taylor, F.Y. Xu, B.J. Ma, T.C. Mutter, V.W. Dolinsky, G.M. Hatch, Expression of monolysocardiolipin acyltransferase activity is regulated in concert with the level of cardiolipin and cardiolipin biosynthesis in the mammalian heart., BMC Biochem. 3 (2002) 9. doi:10.1186/1471-2091-3-9. 
Figure legends

Figure 1: Liver mitochondrial mass is unchanged during cancer cachexia. (A) mitochondrial area quantification with (B) and (C) example of electron microscopy image from liver of PF and PCC rat. Values represent the mean \pm SEM. Pair-fed rats (PF, white bar) and peritoneal carcinosis induced cachexia rats (PCC, black bar) with $\mathrm{N}=3$ per group.

Figure 2: Liver PGPS gene expression is upregulated in cancer cachexia. (A) CDS1 relative expression normalized to $18 \mathrm{~S}$ mRNA, (B) activity and (C) PGPS relative expression normalized to 185 mRNA (D) PGPS activity. Values represent the mean \pm SEM. Pair-fed rats (PF, white bar) and peritoneal carcinosis induced cachexia rats (PCC, black bar) with $\mathrm{N}=7$ per group. ${ }^{*} \mathrm{p}<0.05$ compared to PF.

Figure 3: Liver CLS activity is decreased whereas CL remodeling enzymes are upregulated in cachectic rats. (A) CLS relative expression normalized to $18 \mathrm{~S}$ mRNA, (B) CLS protein expression normalized by Hsc70 protein expression, (C) CLS activity, (D) MLCL AT-1 liver activity and (E) TAZ relative expression normalized to $18 \mathrm{~S}$ mRNA. Values represent the mean \pm SEM. Pair-fed rats (PF, white bar) and peritoneal carcinosis induced cachexia rats (PCC, black bar) with $\mathrm{N}=7$ per group. ${ }^{*} \mathrm{p}<0.05$ compared to PF.

Figure 4: TNF $\alpha$ treatment of HepaRG cells results in increased CL content without modification of mitochondrial mass. Cells were treated for $12 \mathrm{~h}$ with $20 \mathrm{ng} / \mathrm{ml}$ of TNF $\alpha$. (A) Mitochondrial phospholipid content with Cardiolipin (CL), phosphatidylethanolamine (PE), phosphatidylinositol (PI), phosphatidylcholine and phosphatidylserine (PC+PS), and sphyngomyelin [SM]. Values represent the mean \pm SEM ( $N=6$ per group). White bars: control treatment; black bars: TNF $\alpha$ treatment. ${ }^{*} p<0.05$, compared to control treatment. (B) Mitochondrial area in \% of HepaRG area. (C) and (D) example of electronic microscopic images of HepaRG cells in control condition and TNF $\alpha$ treatment, respectively.

Figure 5: TNF $\alpha$ treatment of HepaRG cells results in increased $\mathrm{O}_{2}$ consumption. Cells were treated for $12 \mathrm{~h}$ with $20 \mathrm{ng} / \mathrm{ml}$ of TNF $\alpha$ and then high resolution respirometry performed on (A) intact cells or on (B) 
permeabilized cells using pyruvate, malate and succinate as substrate. Values represent the mean oxygen $\left(\mathrm{O}_{2}\right)$ consumption ( $\mathrm{pmol} / \mathrm{min} / 10^{6}$ cells) \pm SEM ( $\mathrm{N}=6$ per group). White bars: control treatment; black bars: TNF $\alpha$ treatment. ${ }^{*} p<0.05,{ }^{* *} p<0.01$ compared to control treatment.

Figure 6: TNF $\alpha$ treatment results in increased PGPS gene expression in HepaRG cells. Gene expression of (A) PGPP, (B) PGPS, (C) CLS, (D) MLCL AT-1, (E) Tafazzin and (F) ALCAT1. Cells were treated for $12 \mathrm{~h}$ with $20 \mathrm{ng} / \mathrm{ml}$ of TNF $\alpha$. Total RNA was isolated and mRNA expression of the above genes determined. Values are normalized by GAPDH expression. Values represent the mean \pm SEM ( $N=9$ per group). White bars: control treatment; black bars: TNF $\alpha$ treatment. ${ }^{* * * *} \mathrm{p}<0.0001$, compared to control treatment.

Figure 7: TNF $\alpha$ treatment of HepaRG cells increases MLCL AT-1 activity. HepaRG cells were treated for $12 \mathrm{~h}$ with $20 \mathrm{ng} / \mathrm{ml}$ of TNFa and activity of (A) CDS1, (B) PGPS, (C) CLS and (D) MLCL AT-1 determined. Values represent the mean \pm SEM ( $N=5$ per group). White bars: control treatment; black bars: TNF $\alpha$ treatment. ${ }^{*} p<0.05$ compared to control cells.

Figure 8: TNF $\alpha$ treatment of HepaRG cells affects fatty acid molecular species composition. HepaRG cells were treated for $12 \mathrm{~h}$ with $20 \mathrm{ng} / \mathrm{ml}$ of TNF $\alpha$ and CL fatty acid molecular species were analyzed (in $\%$ of total $\mathrm{CL}$ molecular species). Values represent the mean \pm SEM ( $N=6$ per group). White bars: control treatment; black bars: TNF $\alpha$ treatment. ${ }^{*} p<0.05,{ }^{* *} p<0.01$ compared to control treatment.

Figure 9: TNF $\alpha$ treatment does not affect $\mathrm{CL}$ content in HepaRG siPGPS cells. HepaRG cells (siPGPS) were treated for $12 \mathrm{~h}$ with $20 \mathrm{ng} / \mathrm{ml}$ of TNF $\alpha$. Cardiolipin content (CL) in siPGPS HepaRG cells +/- TNF $\alpha$. Values represent the mean \pm SEM (gene expression: $N=4$ per group; cardiolipin content: $N=4$ per group). White bars: control treatment; black bars: TNF $\alpha$ treatment. 


\section{Figures}

Figure 1: Liver mitochondrial mass is unchanged during cancer cachexia

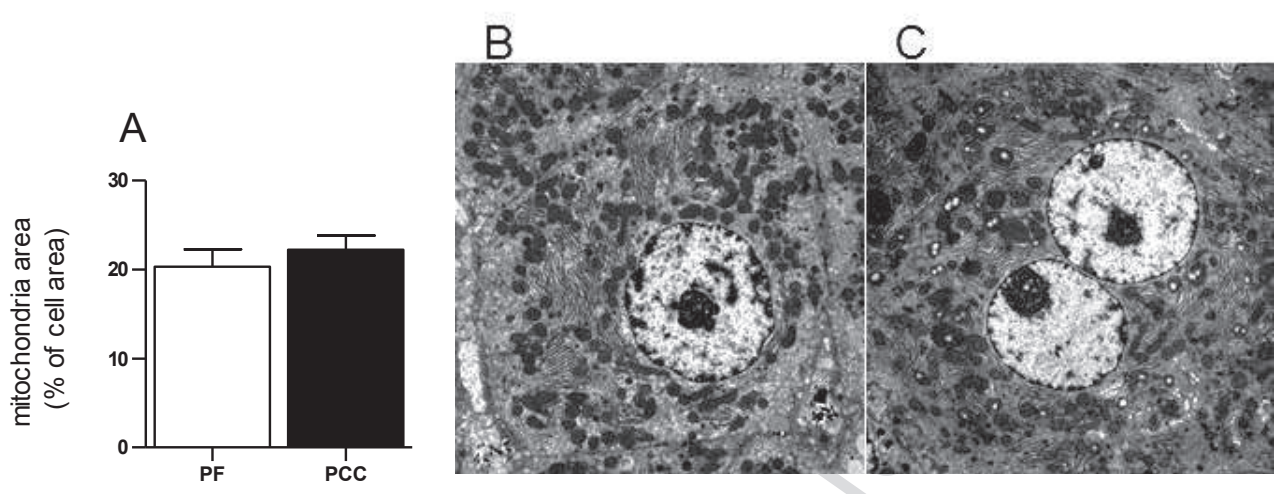


Figure 2: Liver PGPS gene expression is upregulated in cancer cachexia.
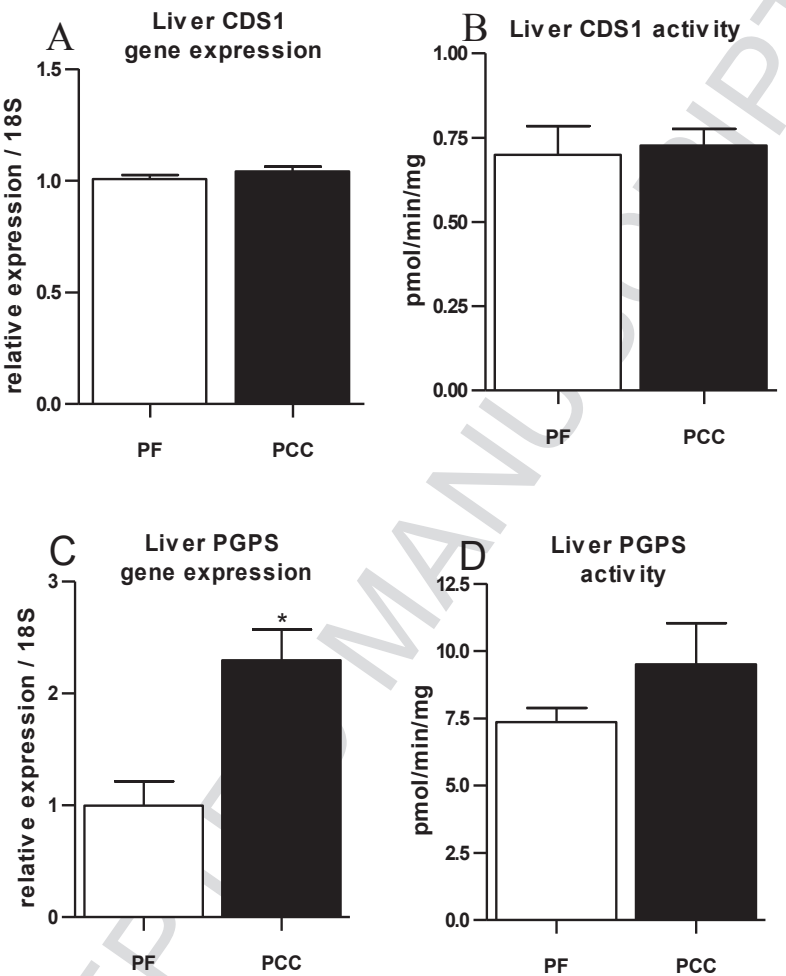
Figure 3: Liver CLS activity is decreased whereas $\mathrm{CL}$ remodeling enzymes are upregulated in cachectic rats.
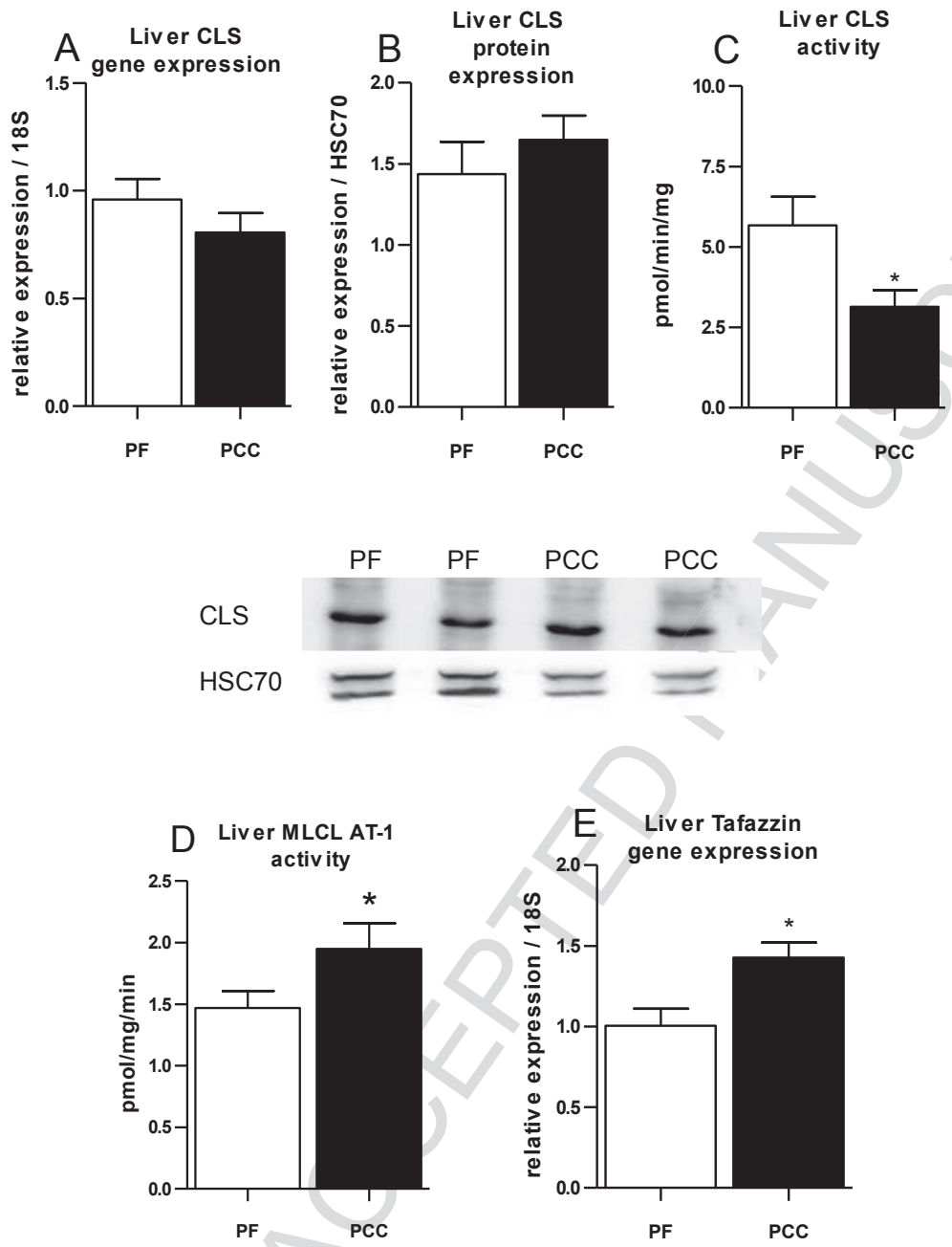
Figure 4: TNF $\alpha$ treatment of HepaRG cells results in increased CL content without modification of mitochondrial mass.

A Mitochondrial phospholipid classes content
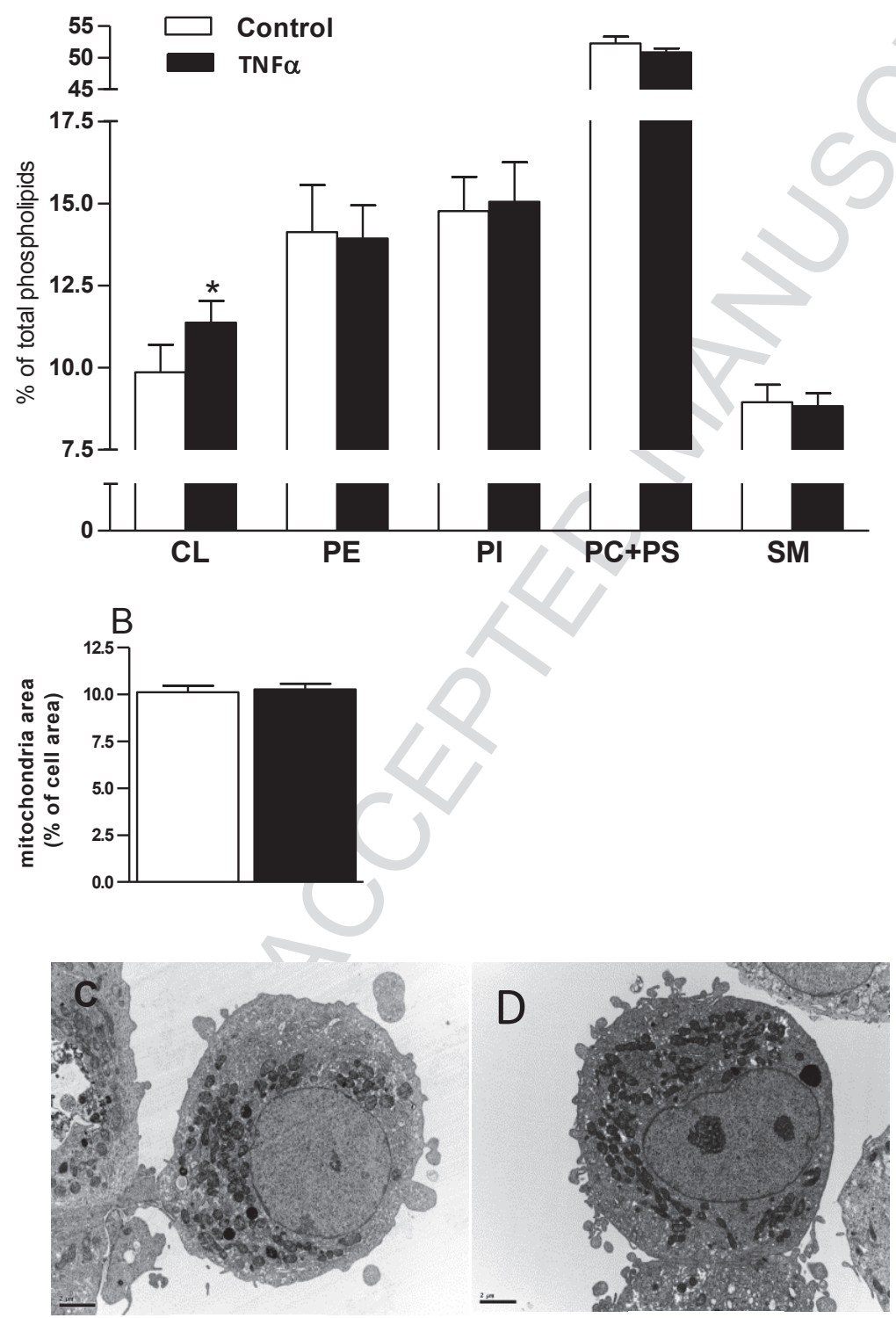
Figure 5: TNF $\alpha$ treatment of HepaRG cells results in increased $\mathrm{O}_{2}$ consumption.
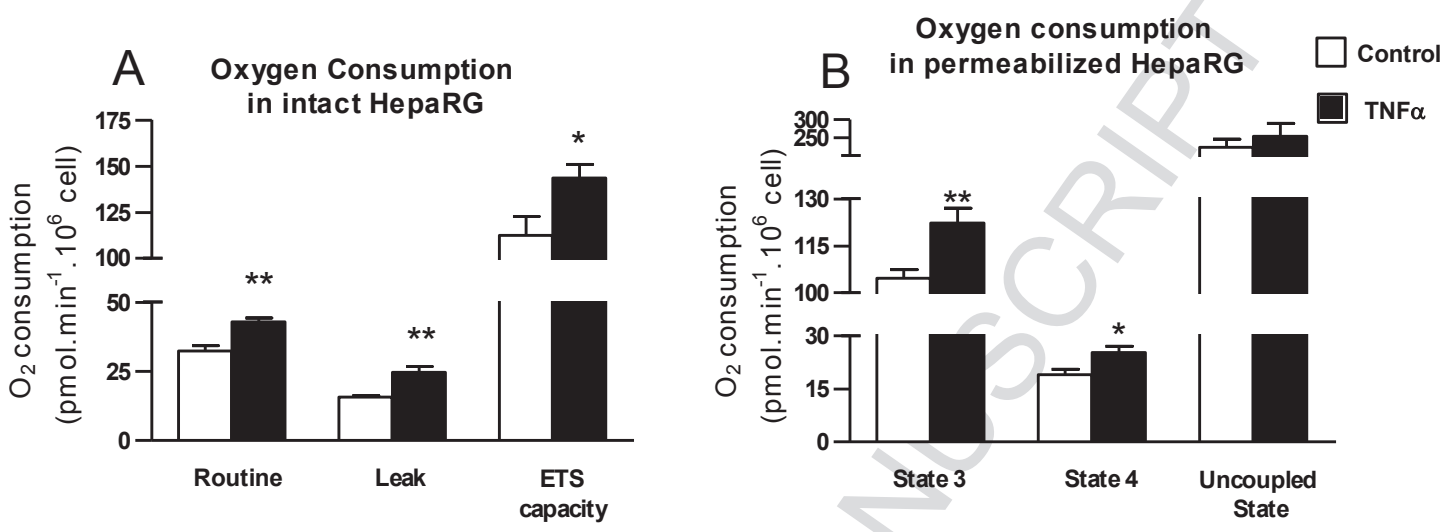
Figure 6: TNF $\alpha$ treatment results in increased PGPS gene expression in HepaRG cells.
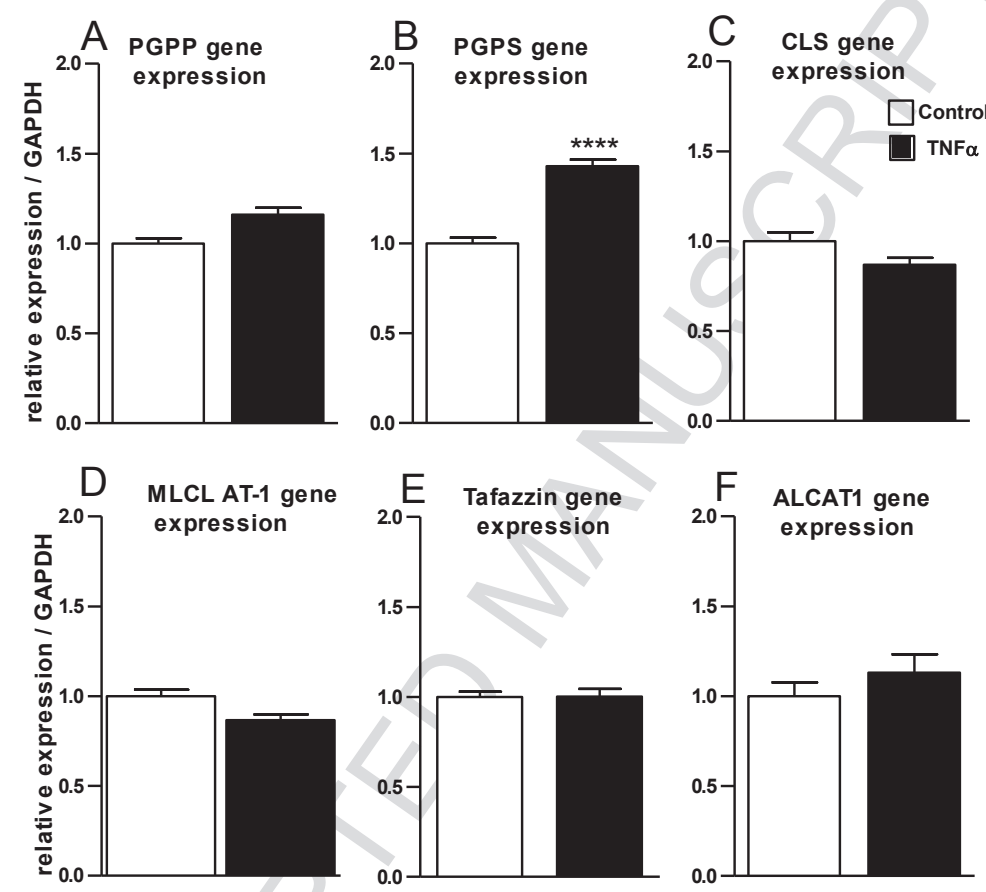
Figure 7: TNF $\alpha$ treatment of HepaRG cells increases MLCL AT-1 activity.
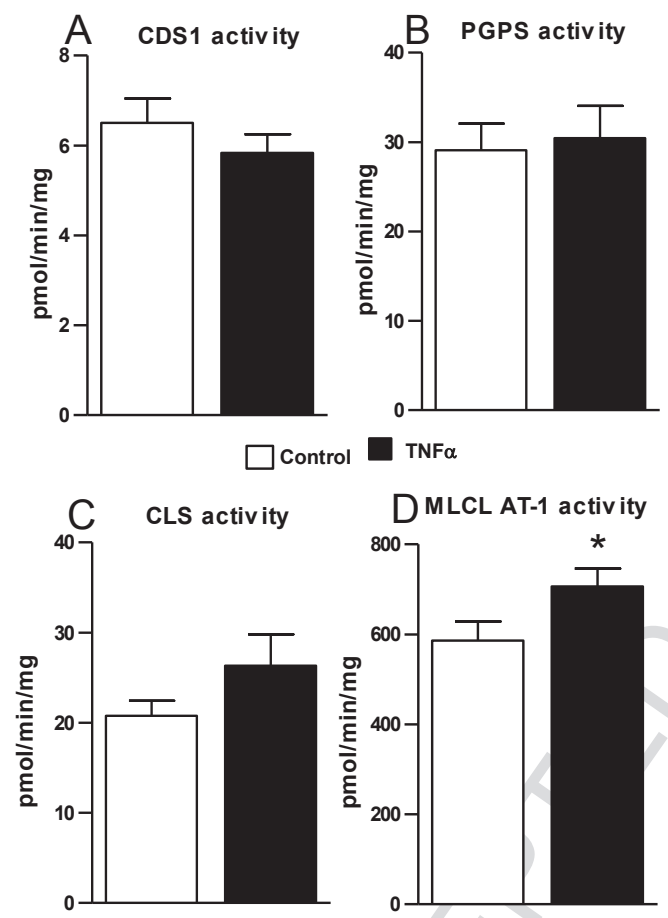
Figure 8: TNF $\alpha$ treatment of HepaRG cells affects fatty acid molecular species composition.

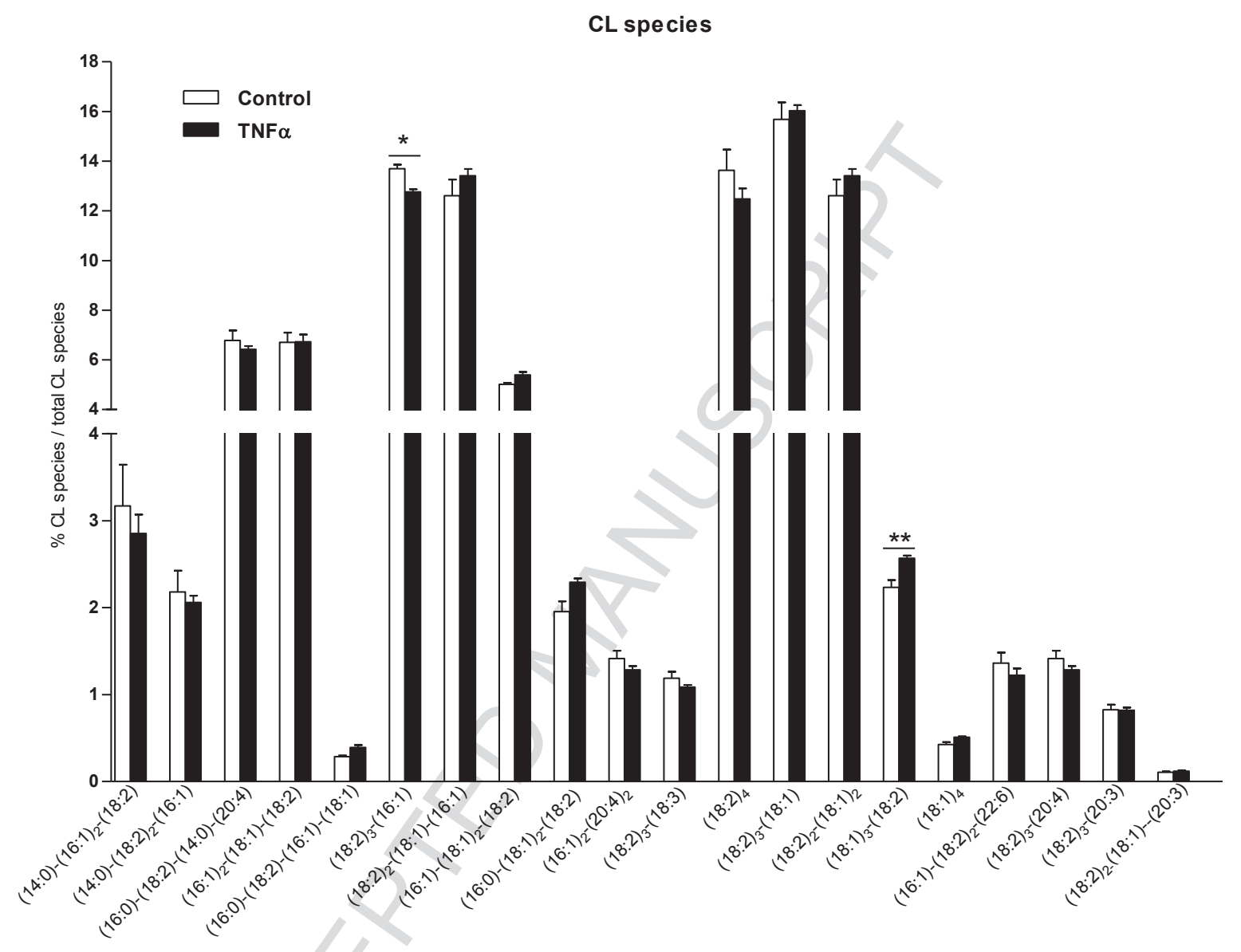


Figure 9: TNF $\alpha$ treatment does not affect CL content in HepaRG siPGPS cells

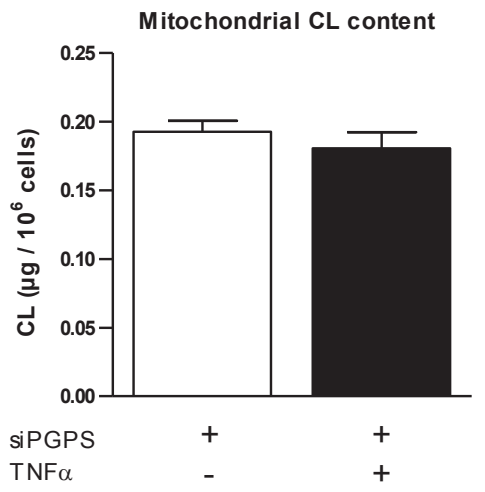




\section{Conflict of interest}

All the authors of the article "Regulation of hepatic cardiolipin metabolism by TNF $\alpha$ : implication in cancer cachexia" submitted to BBA- Molecular and Cell Biology of lipids, declare no conflict of interest.

Laure Peyta, Kathleen Jarnouen, Michelle Pinault, Cedric Coulouarn, Cyrille Guimaraes, Caroline Goupille, Jean-Paul Pais de Barros, Stephan Chevalier, Jean-François Dumas, François Maillot, Grant M. Hatch, Pascal Loyer and Stephane Servais have nothing to disclose. 